\title{
Na tropie dyskursu traumy w metodologicznej samowiedzy pedagogicznej
}

\section{KEYWORDS}

pedagogy, pedagogy's identity, methodology of educational research, selfknowledge, cultural trauma, the trauma discourse

\begin{abstract}
Spychalska-Stasiak Justyna, Na tropie dyskursu traumy w metodologicznej samowiedzy pedagogicznej [Tracing the trauma discourse in the methodological self-knowledge of pedagogy]. Kultura - Społeczeństwo - Edukacja nr 2(12) 2017, Poznań 2017, pp. 245-272, Adam Mickiewicz University Press. ISSN 2300-0422. DOI 10.14746/kse.2017.12.12.
\end{abstract}

This article is theoretical and corresponds with the one of the key discussion areas about pedagogy's identity. The subject of the discussion is methodological pedagogical self-knowledge assumed as the se of pedagogical judgements and images about pedagogy as scientific discipline, its knowledge and research practice. The first part deals with the identity problem of pedagogy as a scientific discipline. The second part covers the relationship among methodological culture, knowledge and pedagogical research practice. The third part concerns the phenomenon of pedagogical self-knowledge and, in particular, the areas of its regulation and its production need in relation to three temporarily differentiated context for the development of the pedagogy's identity. The experience of this changes correspond with specific way of creating pedagogical knowledge, based on the assumptions of trauma discourse.

\section{Wstęp}

W ciągu ostatniego dziesięciolecia wnikliwe oko krytyki naukowej skierowane zostało na praktykę pedagogicznych badań naukowych. Zainteresowani metodologią badań pedagogicznych badacze oraz badaczki dokonują syntetycznego podsumowania tego, co i w jaki sposób bywa w pedagogice badane. Zagadnieniem nie mniej ważnym staje się status wytworzonej na tej podstawie wiedzy. Efektem owej tendencji jest zbiór 
tematycznie powiązanych publikacji naukowych ${ }^{1}$, których autorzy oraz autorki rekonstruują metodologiczne podstawy badawczej aktywności pedagogów. Z wypracowanej na tej podstawie autocharakterystyki można wysunąć co najmniej trzy wnioski:

1) zarówno pedagogika, jak i nauki pokrewne $e^{2}$ wciągnięte zostały w wir niemożliwej do zatrzymania zmiany, definiowanej w przypadku rodzimej dyscypliny jako przejście od ortodoksji ku heteronomii myślenia pedagogicznego (Hejnicka-Bezwińska, 1989; 2008; 2011);

2) intensywne tempo dokonujących się w nauce zmian, a także stopień wyrastających na jego podstawie modyfikacji, wywołują szereg trudności, problemów i dylematów, utrudniających pedagogom konieczność „uczestniczeni[a] w metodologicznej zmianie” (Piekarski, 2013: 24),

3) diagnozowanie owych trudności, ich opisywanie, analizowanie i wyjaśnianie stanowi jeden z podstawowych toposów metodologicznej samowiedzy pedagogicznej.

Szczegółowa charakterystyka przedstawionych powyżej wniosków doprowadziła do wyodrębnienia trzech zasadniczych części niniejszego artykułu. Pierwsza z nich, zatytułowana $O$ pedagogice spod znaku zmian, odnosi się do problemu kształtowania tożsamości pedagogiki jako dyscypliny naukowej. W części drugiej: Metodologiczne aspekty uprawiania pedagogiki spod znaku zmian dokonuję charakterystyki relacji występującej pomiędzy kulturą metodologiczną, wiedzą oraz praktyką badań pedagogicznych. W części ostatniej, zatytułowanej Metodologiczna samowiedza pedagogiczna w kontekście przemian tożsamości pedagogiki jako dyscypliny naukowej, koncentruję się na zjawisku metodologicznej samowiedzy pedagogicznej. Charakteryzuję jej podstawowe cechy, płaszczyzny regulowania oraz możliwość jej wytwarzania w niejednorodnym kontekście rozwoju tożsamości pedagogiki jako dyscypliny naukowej.

\section{O pedagogice spod znaku zmian}

Ewolucja tożsamości pedagogiki, rozumianej zarówno jako dyscyplina naukowa (zob. Hejnicka-Bezwińska, 2008), jak i społeczna praktyka edukacyjna (zob. Palka,

\footnotetext{
${ }^{1}$ W kontekście sygnalizowanych powyżej tendencji znaczenia szczególnego nabierają takie pozycje jak: Piekarski, Urbaniak-Zając, Szmidt, 2010 oraz Bauman, 2013. Pojedyncze artykuły odnoszące się problemu tworzenia wiedzy pedagogicznej znajdują się w Kubinowski, Nowak, 2006 oraz w Rubacha, 2008a.

${ }^{2}$ Interesującą perspektywę powiązań występujących pomiędzy pedagogiką a innych dyscyplinami naukowymi prezentują autorzy tekstów umieszczonych w publikacji wydanej pod redakcją Stanisława Palki (2004) pt. Pogranicza pedagogiki i nauk pomocniczych.
} 
2011) wpisana została w proces szeroko następujących zmian, o których Zbigniew Kwieciński (2011: 13) pisze w sposób następujący:

Na przełomie lat osiemdziesiątych i dziewięćdziesiątych dokonały się zasadnicze przejścia polityczne, gospodarcze i kulturowe ogarniające nie tylko całą Polskę, nie tylko Europę Środkowo-Wschodnią, ale i cały świat. Tak fundamentalne zwroty muszą wywoływać pytania o to, jakie są ich implikacje dla szeroko pojętego wychowania czy edukacji, dla celów, form i treści kształcenia, dla sposobów myślenia (ideologii, paradygmatów, metod, nurtów) o tych procesach i uprawiania badań i studiów nad nimi. Są to też pytania o samą pedagogikę i o jej przemiany w tym okresie w związku z owymi gruntownymi przejściami.

Próba sformułowania zobowiązującej dla polskiego środowiska pedagogicznego odpowiedzi na postawione w przytoczonym cytacie pytania przybierała charakter swoisty:

1) osadzony w historycznej kondycji państwa polskiego;

2) jego ustrojowego przełomu;

3) politycznego chaosu;

4) ideologicznych odwrotów oraz powrotów;

5) dynamicznie zmieniającego się rynku.

Zdaniem Teresy Hejnickiej-Bezwińskiej (2011:38) za kulturowy kontekst rozważań o ewolucji tożsamości pedagogiki uznać należy „proces włączania nauki polskiej i edukacji w kulturę realnego socjalizmu (kryzys I), a potem kontekst odchodzenia od kultury realnego socjalizmu i ponownego włączania w kulturę demokratyczną i rynkową (II kryzys pedagogiki)". Każdy z zasygnalizowanych w powyższym cytacie kryzysów miał zatem swoje temporalnie dookreślone spectrum ważkich problemów do rozwiązania. Ich charakterystykę, w sposób skrótowy, ujmuję jako stan angażującego poznawczo i emocjonalnie przejścia: od konieczności wypracowania tak środowiskowej, jak i indywidualnej strategii przetrwania w warunkach przypadającej na lata 50. 60. i 70. ofensywy ideologicznej ${ }^{3}$ do ustanowienia zgoła odmiennych od dotychczasowych zadań przewidzianych dla praktyki edukacyjnej oraz pedagogiki jako dyscypliny naukowej. Aksjologicznym drogowskazem dla tworzenia podwalin ówcześnie konstytuującej się tożsamości pedagogiki stały się ustalenia poczynione w ramach I Zjazdu Pedagogicznego w Warszawie-Rembertowie, zorganizowanego w roku 1993. W trakcie obrad nie tylko zanegowano dotychczasowy dorobek naukowej pedagogiki socjalistycznej ${ }^{4}$,

3 Ofensywa ideologiczna rozumiana jest jako „program zmian świadomości społecznej w doktrynie komunistycznej ZSRR. Głównym obiektem i obszarem oddziaływań była kultura” (Hejnicka-Bezwińska, 2008: 491).

${ }^{4}$ Naukowa pedagogika socjalistyczna to „szczególna odmiana pedagogiki empirycznej, wpisującej się w pozytywistyczny model wytwarzania wiedzy naukowej, ale zredukowana do jednej 
ale zwrócono także uwagę na „uznanie równoprawności, a nawet potrzebę różnych ujęć pedagogiki i różnych sposobów jej uprawiania. Wtedy też zaakceptowano propozycję, aby pedagogikę spostrzegano wielowymiarowo czy wielopłaszczyznowo: jako samodzielną naukę, jako obszar badań pedagogicznych, jako refleksję o wychowaniu, jako praktykę społeczną i jako pedagogię" (Lewowicki, 2006: 24-25). Heterogeniczność stała się zatem środowiskowo ustanowionym faktem, a decyzje podjęte przez ówczesnych pedagogów wyznaczyły trajektorię rozwoju tej dyscypliny.

Na proces wewnętrznej przemiany pedagogiki nałożyło się również zjawisko okcydentalizmu, rozumiane jako „zwrot ku Zachodowi jako układu pewnego odniesienia politycznego, gospodarczego i kulturowego, a zarazem odwrót od w dużej mierze narzuconych przywiązań do Związku Radzieckiego i Rosji” (Kwieciński, 2011: 13). Jego zaistnienie ukonstytuowało „optymistyczną wizję pedagogiki bez granic": 1) dyskutującej z tradycyjnym gorsetem jej tożsamości, 2) inspirowanej interdyscyplinarnym dorobkiem rodzimych nauk społecznych i humanistycznych, 3) umocowanej w globalnie podtrzymywanej sieci międzynarodowych kontaktów naukowych i spluralizowanego na ich podstawie rynku idei (Melosik, 2003). Odbywane w latach 90 . staże w zagranicznych ośrodkach naukowych, realizowane stypendia oraz intelektualne efekty zagranicznych kwerend bibliotecznych zaowocowały wzbogaceniem polskiego rynku wydawniczego o tłumaczone z języków obcych pozycje. Mapa nieobecnych jak dotąd dyskursów wysycona została nowymi treściami i perspektywami poznawczego oswajania świata ${ }^{5}$.

Okcydentalizm korespondował więc z pozyskiwaniem świadomości zmian dokonujących się w ówczesnej nauce. Zasadnicze przemiany filozofii nauki oraz będące ich konsekwencją zwroty odnotowane w naukach społecznych i humanistycznych ${ }^{6}$ wiązały się z koniecznością dostrzeżenia niemożliwej do zignorowania

orientacji ideologicznej, dla której jedynym uzasadnieniem było to, że została ona wyprowadzona z postępowej ideologii marksistowsko-leninowsko-stalinowskiej lub jej aktywnej wykładni przyjętej przez Centrum" (Hejnicka-Bezwińska, 2011: 40).

${ }^{5}$ Dobrym przykładem są tutaj prace: Kwieciński, Witkowski, 1990 oraz cykl prac pod redakcją Zbigniewa Kwiecińskiego zatytułowany Nieobecne dyskursy.

${ }^{6}$ Próby uporządkowania i scharakteryzowania wybranych przykładów zwrotu w naukach społecznych i humanistycznych podjęli się autorzy oraz autorki tekstów wydanych w publikacji pt. Zwroty badawcze w humanistyce. Konteksty poznawcze, kulturowe i społeczno-instytucjonalne, wydanej pod redakcją J. Kowalewskiego i W. Piasek. Redaktorzy we wstępie wymieniają czternaście rodzajów zwrotów, które dokonały się we współczesnej humanistyce: „Zwrot antropologiczny, zwrot kulturowy, zwrot darwinowski, zwrot dramaturgiczny, zwrot etyczny, zwrot ikoniczny, zwrot interpretacyjny, zwrot ku rzeczom, zwrot narratywistyczny, zwrot performatywny, zwrot poznawczy, zwrot pragmatyczny, zwrot retoryczny, zwrot topograficzny.... Ponieważ trudno jest uznać, aby tak wypracowana lista miała charakter jednoznacznie domknięty i wyczerpujący, należy się zgodzić się 
istoty przełomu antypozytywistycznego. Wyrastający na jego podstawie pluralizm epistemologicznych, ontologicznych i metodologicznych sposobów myślenia i badawczego działania doprowadził do wytwarzania tożsamości pedagoga-badacza wokół jeśli nie wielu, to przynajmniej dwóch dróg (Rutkowiak, 1995). Świadome pozostawanie w granicach jednego, dobrze rozpoznanego trybu postępowania pozbawione zostało wymiaru „naturalnej oczywistości”, a jako takie powiązane zostało z problemem jego legitymizacji. Postmodernistyczna krytyka oświeceniowych idei rozumu, racjonalności, prawdy, podmiotu, historii i wiedzy uderzyła w trzon pozytywistycznej koncepcji nauki i postawiła pytania o sens współczesnego dociekania naukowego oraz jego rolę w procesie nie tyle odzwierciedlania, co raczej konstruowania wybranych obszarów rzeczywistości (Melosik, 1993; Lyotard, 1997; Benton, Craib, 2003; Fukuyama, 2009; Braidotti, 2013).

Reasumując: zasadnicze przemiany tożsamości pedagogiki wciągnięte zostały w wir szeroko następującej zmiany, przypadającej na okres burzliwych przełomów ostatnich dwustu lat. Swoistość pedagogicznego oswajania praktyki edukacyjnej czerpie z kilku źródeł:

a) doświadczenia przeszłości (pewne sposoby formowania pedagogiki są kontynuacją historyczną wzbogaconą o elementy nowoczesności),

b) doświadczenia teraźniejszości związane[j] z okresami przełomów społecznych, kulturowych, w których stawiane są na nowo pytania o istotę wychowania człowieka,

c) inspiracj[i] poznawcz[ych] i metodologiczn[ych] z dziedzin nauk filozoficznych (z ontologii, epistemologii, antropologii, aksjologii),

d) wzor[ów] czerpan[ych] z nauk pokrewnych o silnie zaznaczonym statusie naukowym i silnej dynamice rozwojowej - przede wszystkim psychologii i socjologii (...) (Palka, 1998: 9).

\section{Metodologiczne aspekty uprawiania pedagogiki spod znaku zmian}

Występujące w pedagogicznej literaturze naukowej ${ }^{7}$ tendencje do osadzania pedagogiki w szeroko rozumianym kontekście kultury umożliwiają wypracowanie dynamicznej perspektywy oglądu zachodzących w jej ramach zmian. W rozdzia-

\footnotetext{
z redaktorami omawianej publikacji, że „zwrot stał się dziś naczelną kategorią organizującą badania humanistyczne, jak i prowadzoną nad nimi refleksję" (Kowalewski, Piasek, 2010: 7).

${ }^{7}$ Czyni tak, między innymi, Teresa Hejnicka-Bezwińska w książce Pedagogika ogólna. Podręcznik akademicki oraz Jacek Piekarski w artykule zatytułowanym Badawcza praktyka i jakość wiedzy - wybrane uwarunkowania, opublikowanym w książce pod redakcją Teresy Bauman Praktyka badań pedagogicznych.
} 
le poprzednim pokazałam, że zasadnicza kondycja interesującej mnie dyscypliny i powstających w jej ramach wytworów jest uwarunkowana zarówno endogennymi (wewnątrznaukowymi), jak i egzogennymi (dotyczącymi nauki i społeczno-kulturowego punktu jej odniesienia) czynnikami zmianotwórczymi. Składają się one z niejednorodnego syndromu warunków, idei oraz zasad warunkujących możliwość wytwarzania wiedzy uznawanej za naukową.

$\mathrm{W}$ odniesieniu do metodologii badań pedagogicznych, wyczerpującego ${ }^{8}$ przeglądu owych czynników zmianotwórczych dokonał, między innymi, Janusz Gnitecki (2001: 19), w artykule zatytułowanym Przemiany metodologii badań pedagogicznych. Według przywołanego autora:

źródeł przemian współczesnej metodologii badań pedagogicznych można doszukiwać się w zmianach dokonujących się w filozofii nauki i ogólnej metodologii nauki, a także antropologii, ontologii, aksjologii i epistemologii edukacji. Zmiany takie są też wynikiem przemian współczesnej cywilizacji, kultury i oświaty - w tym także debaty wokół modernizmu i postmodernizmu prowadzonej w kontekście zarysowujących się megatrendów i tendencji globalizacyjnych współczesnego świata.

Owa wewnętrzno-zewnętrzna determinacja dopuszczalnych sposobów prowadzenia badań ma swoje źródła w metodologicznej kulturze. Jak bowiem twierdzi Knyazheva (2012)

Edukacja potrzebuje generalizacji i podtrzymywania nowego doświadczenia, kształtującego człowieka osadzonego w kulturze, moralności, wiedzy. To staje się kontekstem metodologii. Transmisja kultury czyni działania zorientowanymi na obiekt, daje temu działaniu nową, konkretną i istotną formę, podczas gdy edukacja zapewnia, że informacja zwrotna na temat obiektów i wytworów formuje prawidłową aktywność ludzką, rozwija ją.

Według przywołanej powyżej autorki kultura metodologiczna stanowi fenomen społeczno-kulturowy z trzech powodów:

1) jej praktykowanie podporządkowane zostaje obowiązkowi podtrzymywania i wytwarzania nowych wariantów społeczno-kulturowego doświadczenia;

${ }^{8}$ Janusz Gnitecki dokonuje wnikliwej analizy przemian metodologii pedagogiki w odniesieniu do przewartościowania w filozofii nauki i ogólnej metodologii nauk w zakresie aż piętnastu rodzajów przejść w sposobie wyznaczania standardów naukowości. Nieco inną perspektywę oglądu przemian pedagogiki jako dyscypliny naukowej prezentuje Andrzej Radziewicz-Winnicki w artykule pt. Świadomość społeczna a stan wspólczesnej rodzimej pedagogiki. (Kilka zindywidualizowanych refleksji z perspektywy pedagogiki społecznej). 
2) jej podtrzymywanie wymaga ukształtowania odpowiednio zorganizowanej i ukierunkowanej kultury pedagogicznej;

3) konstytutywna dla niej autokreacja przez wiedzę wymaga w pełni rozwiniętej osobowości badacza, zakotwiczonej w organicznej koegzystencji istoty ludzkiej oraz kultury.

Istota omawianego fenomenu ukształtowana zostaje na styku dwóch komplementarnych względem siebie osi: wertykalnej i horyzontalnej (zob. ryc. 1.).

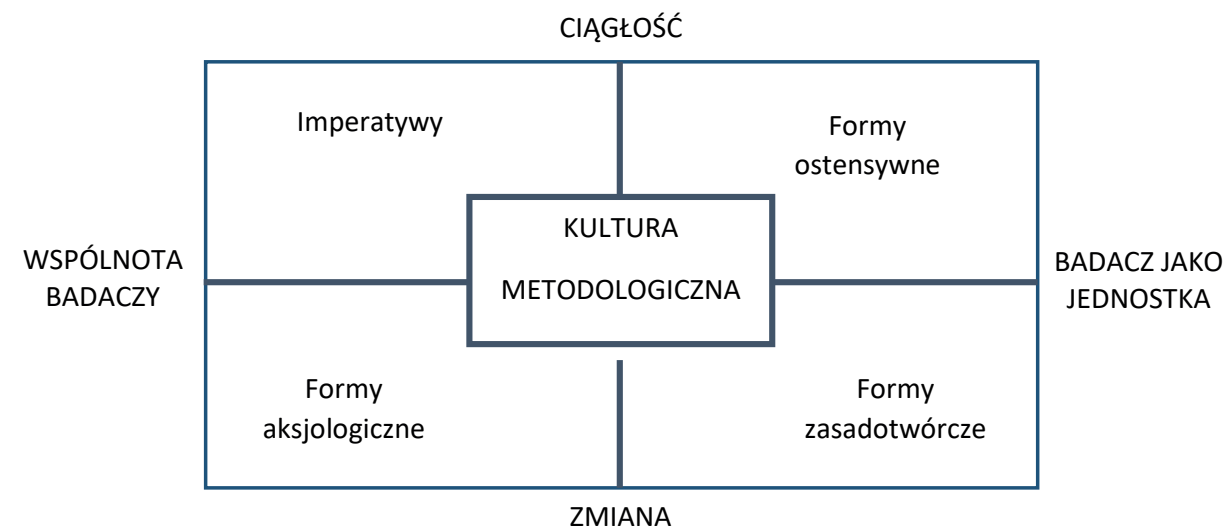

Ryc. 1. Kultura metodologiczna jako fenomen społeczno-kulturowy

Źródło: opracowanie własne na podstawie Knyazheva, 2012

Oś wertykalna osadza kulturę metodologiczną w szeroko rozumianym kontekście kultury, zobowiązującym reprezentantów kapitału nauki do równoczesnego konserwowania i wytwarzania nowych wariantów społeczno-kulturowego doświadczenia:

W specjalnie zorganizowanej aktywności poznawczej ujawniają się obiekty idealne. Z jednej strony są one analizowane i opisywane w wiedzy, z drugiej, rozwijają się ze specyficznych procedur stosowania wiedzy naukowej, powiązanej z prawdziwymi empirycznymi obiektami. (Knyazheva, 2012)

Oś horyzontalna akcentuje z kolei zbiorową i jednostkową płaszczyznę kultury metodologicznej. Płaszczyzna zbiorowa wyznaczona zostaje przez poziom rozwoju metodologicznej i pedagogicznej tradycji, norm, reguł, wartości oraz teorii utrzymujących się w środowisku uczonych. Płaszczyzna jednostkowa odnosi się z kolei do zestawu indywidualnie zinternalizowanych „metodologicznych 
i pedagogicznych kanonów, zwyczajów, wytycznych, wartości, idei oraz koncepcji” (Knyazheva, 2012).

Podczas gdy oś wertykalna podkreśla otwartość kultury metodologicznej na kontekst społeczno-kulturowy, oś horyzontalna eksponuje jej środowiskowe zamknięcie i wewnętrzne zróżnicowanie. Elementem łączącym konstytutywne dla omawianych osi cechy jest ich osadzenie w nieredukowalnym kontekście ciągłości i zmiany:

Sekwencja uniwersalnych form podtrzymywania i przekazywania ludzkiego potencjału wyraża się, z jednej strony, historyczną logiką rozwoju kultury w ogóle i jej podstawowych typów, z drugiej strony, logiką kulturowej inkluzji istoty ludzkiej. Logika form kulturowych jest zobiektywizowana w typach kultury. (Knyazheva, 2012)

W przypadku kultury metodologicznej funkcję owych form kulturowych odpowiedzialnych za konserwację oraz transformację społecznego doświadczenia pełnią: imperatywy, formy ostensywne (zwane również demonstracyjnymi), aksjologiczne i zasadotwórcze. Ich szczegółowa charakterystyka przedstawiona została $\mathrm{w}$ tabeli 1.

Imperatywy kulturowe należą do tych regulatorów aktywności badawczej człowieka, które obligują do „odpowiedzialności, rozpoznania absolutu wymagań i przyjęcia występowania pewnego dystansu” (Knyazheva, 2012). Tworzące je treści stanowią trzon akademickiej kultury naukowej, wymagającej od depozytariuszy przynależnego jej kapitału ukształtowania odpowiedniego „zakresu wiedzy i umiejętności praktycznych z zakresu metodologii danej dziedziny lub dyscypliny naukowej, znajomości historii idei naukowych, problemów fundamentalnych dla zrozumienia specyfiki danej dziedziny naukowej, teorii kanonicznych, potencjalnych środowiskowych i personalnych zagrożeń dla rozwoju badań" (Górniewicz, Piotrowski, 2014: 186). Ich funkcjonowanie podporządkowane zostaje zasadzie: „istotna społecznie działalność nie powinna zniknąć; powinna zostać podtrzymana w przyszłości, wywodzącej się z przeszłości i rozszerzyć się" (Knyazheva, 2012). Jako element składowy świadomości naukowej obejmują swoim zakresem co najmniej 500 lat zróżnicowanych doświadczeń ludzkości w zakresie poznawczego oswajania świata. Prócz swojej formalnej i uniwersalnej wymowy cechują się również wewnętrznym zróżnicowaniem, a nawet sprzecznością występujących w ich ramach dyrektyw, instrukcji oraz idei. Jak bowiem twierdzi Marek Sikora (2013: 293)

nauka nie jest budowana na indukcyjnej akumulacji wiedzy absolutnie prawdziwej. Konstytuuje ją przede wszystkim metodologiczna zasada samokontroli. Zasada ta sprawia, że wszystkie wytwory nauki są otwarte na rewizje, na modyfikację, a nawet na odrzucenie w wyniku ujawniania coraz to nowych doświadczeń. 


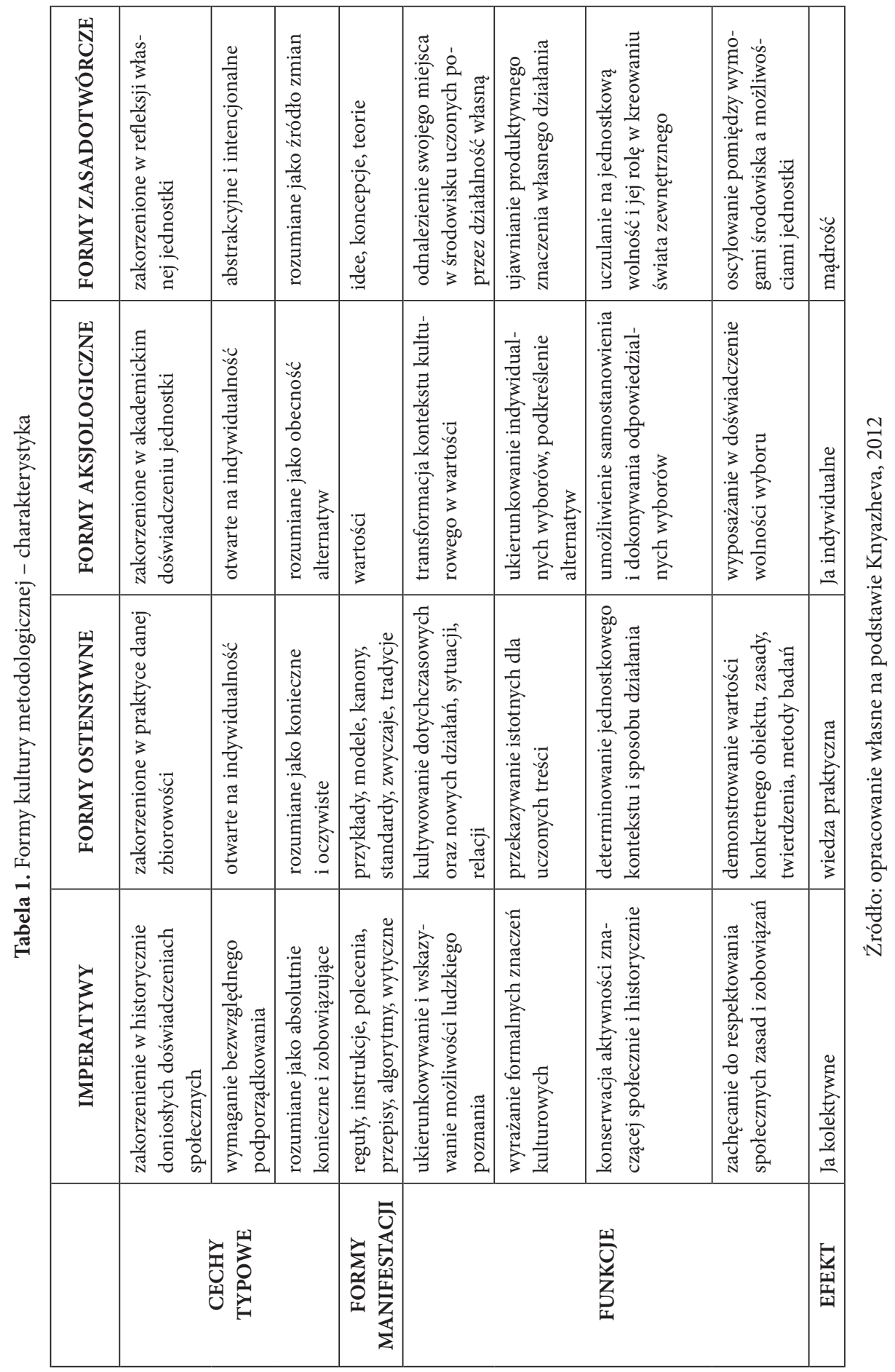


Abstrakcyjna istota metodologicznych imperatywów kultury sprowadzona zostaje na poziom badawczej praktyki za pomocą form ostensywnych.

\begin{abstract}
Asymilacja elementów kultury za pomocą środków demonstracji (rób tak jak ja) staje się możliwym przedmiotem identyfikacji z tym, który je proponuje, rozumiejąc siebie jako część określonej społeczności, akceptując tę społeczność, wrastając w nią, uwewnętrzniając jej standardy i uświadamiając sobie je jako własne. (Knyazheva, 2012)
\end{abstract}

Imperatywy kulturowe przybierają więc za ich pomocą formę konkretnego wytworu naukowego, wiedzy i umiejętności, a także określonego trybu działania. Ich kultywowanie dokonuje się zatem w ramach konkretnej szkoły naukowej, będącej, zdaniem Miloslava Petruska (1994: 16 za Śliwerski, 2009: 32-33),

grupą naukowców, którzy kontaktują się i komunikują ze sobą bezpośrednio lub pośrednio, rozwiązują zbieżne problemy badawcze, kierują się tymi samymi przesłankami teoretycznymi i podstawowymi założeniami metodologicznymi, odwołują się do tych samych uznawanych autorytetów i skupiają się wokół wspólnego żyjącego autorytetu lub programowo nawiązują do jego dzieł.

Można więc zauważyć, że ostensywne formy kultury metodologicznej „wydzielają" z uniwersum naukowego sposobu oswajania świata specyficzne wiązki teoretyczno-metodologicznych podstaw badawczego działania, wyposażających badacza w wiedzę praktyczną, „rozumianą jako nawyk jednostki w sytuacji konkretnej komunikacji i działania praktycznego, w których to jednostka odnajduje samą siebie i nie wymaga żadnego refleksyjnego wysiłku” (Knyazheva, 2012).

Z drugiej strony: „działanie podejmowane na podstawie doświadczenia, ocen, rozwiązań, alternatywnych wyborów (cnota-zło, prawda-fałsz, szczęście-niedola) inicjuje ekspresję własnego Ja, jako podstawę wybranej drogi” (Knyazheva, 2012).

Wolność dokonywania świadomego wyboru pomiędzy programowo zróżnicowanymi szkołami myślenia, pomiędzy bezpiecznym praktykowaniem konstytutywnego dla nich zespołu idei, a ich odważnym przełamywaniem, stanowi z kolei domenę aksjologicznych form kultury metodologicznej. Zdaniem Knyazhevy (2012),

wartości determinują wybór i cel drogi oraz znaczeń, które definiują ich osobistą i społeczną istotność. To jest obecność alternatyw, która konstytuuje kulturową i abstrakcyjną zawartość form aksjologicznych, wyposażających jednostkę w doświadczenie wolności - wolności od natychmiastowych społecznie zobiektywizowanych wymogów - i pozwala na autodeterminację oraz świadomość odpowiedzialnych wyborów. (Knyazheva, 2012) 
Możliwość oscylowania pomiędzy „tak i nie, pomiędzy poprawnością i czymś, co nie jest zgodne z wartościami indywidualnymi i publicznymi” (Knyazheva, 2012) stanowi punkt wyjścia dla możliwości powstania takich form kultury metodologicznej, które umożliwiają ustanawianie zasad:

Formy zasadotwórcze są najbardziej abstrakcyjnymi formami kulturowej transmisji znaczeń, gdzie zdolność wyrażenia czegoś interpretuje siebie jako swoje własne źródło i sprawia, że te wyrażenia są refleksyjne i zdolne do generowania samych siebie. (Knyazheva, 2012)

Ich konceptualizacja traktowana jest jako przejaw metodologicznej mądrości, umożliwiającej umiejętne oscylowanie pomiędzy jednostkowo ukształtowaną preferencją badacza a wymogami kultury uniwersyteckiej.

\begin{abstract}
Kultura metodologiczna jako fenomen społeczno-kulturowy powstała z potrzeby ustalenia kanałów komunikacji pomiędzy istniejącymi i wyłaniającymi się praktykami pedagogicznymi, przypisanymi do akumulacji wiedzy pedagogicznej, której źródłem jest, z jednej strony praktyka, a z drugiej idee, integrujące różne rodzaje wiedzy pedagogicznej na różnych płaszczyznach. (Knyazheva, 2012)
\end{abstract}

Zdaniem Stanisława Palki (2010: 17-20) intelektualne zasoby depozytariuszy kapitału pedagogiki mają swoje źródła w dwóch rodzajach wiedzy:

1) wiedzy w pedagogice;

2) wiedzy pedagogicznej.

Zakres pojęcia „wiedza w pedagogice” jest szeroki. Mieszczą się w nim interdyscyplinarne pokłady wiedzy uznawanej za „użyteczną do poznania pedagogicznego i do praktycznej działalności pedagogicznej”. Pojęcie „wiedza pedagogiczna” ma zatem charakter zakresowo węższy i odnosi się do poznawczych efektów badania osadzonego w granicach konkretnej dyscypliny naukowej (tutaj pedagogiki). O ile więc pierwsze z przytoczonych powyżej pojęć bazuje na wykorzystaniu interdyscyplinarnych zasobów wiedzy naukowej, o tyle drugie akcentuje jej specjalizację (Boguski, 2013). „W pedagogice obie kategorie wiedzy są ujmowane łącznie, co umożliwia zarówno pełniejsze poznawanie, jak i skuteczniejsze działania praktyczne" (Palka, 2010: 19). (Po)zyskujący je badacz wyposażony zostaje w takie składniki wiedzy teoretycznej, jak: „fakty, zjawiska, prawa, twierdzenia, procesy, teorie, modele, systemy, kategorie, typologie, klasyfikacje i hipotezy", a także w takie zasoby wiedzy praktycznej, które umożliwią mu efektywne przeprowadzenie planowanego badania.

Zaakcentowany przez Palkę mariaż wiedzy pedagogicznej i wiedzy w pedagogice unaocznia się w kondycji wiedzy metodologicznej, obejmującej zarów- 
no „formułowanie problemów badawczych, wynikających z dziedziny poznania danej dyscypliny naukowej, jak i spos[oby] postępowania badawczego służące rozwiązywaniu tych problemów oraz gromadzenia danych, opracowywania, analizowania i interpretowania tych danych (Palka, 2010: 22-23)". Jej wytwarzaniem zajmuje się głównie metodologia, rozumiana przez Kazimierza M. Czarneckiego (2009: 102) jako:

1) nauka o metodach wszelkiego skutecznego działania ludzkiego (metodologia ogólna), której przedmiotem są metody badań naukowych, ich naukowa wartość, poprawność, przydatność;

2) w znaczeniu węższym: nauka o metodach badania naukowego, czyli metodologia nauk, w której wyróżnia się ogólną metodologię, zajmującą się problematyką związaną $\mathrm{z}$ analizą oraz oceną metod i działań poznawczych wspólnych dla wszelkiej działalności naukowej, na przykład: metody zbierania i analizy materiału empirycznego, formułowanie i uzasadnianie twierdzeń, klasyfikacja materiału badawczego, wnioskowanie dedukcyjne;

3) metodologia danej dyscypliny naukowej ukazująca normy postępowania badawczego, których spełnienie stanowi warunek konieczny do uzyskania wiedzy naukowej.

Z przedstawionego powyżej sposobu rozumienia metodologii można wysunąć następujące wnioski, odnoszące się wiedzy metodologicznej. Wytwarzana w omawianej dyscyplinie wiedza metodologiczna ma bowiem charakter:

1) interdyscyplinarny, uwzględniający zarówno „historyczny (historia nauki i techniki), socjologiczny (socjologia wiedzy), ekonomiczny (planowanie w nauce), logiczny (struktura logiczna nauki), metodologiczny (logika naukowego odkrywania i uzasadniania), filozoficzny (filozofia nauki)" kontekst działania naukowego (Goriszowski, 2006);

2) teoretyczny i praktyczny. Dokonania metodologii teoretycznej otwierają przed badaczem możliwość metateoretycznego i metarefleksyjnego spojrzenia na prowadzony przez niego proces. Dyrektywy metodologii praktycznej zmierzają do usprawnienia jego przebiegu, podniesienia efektywności oraz kontrolowania jakości uzyskanych efektów (zob. Rubacha, 2008b);

3) oscylujący pomiędzy uniwersalną dyrektywą profesjonalnego i rzetelnego postępowania metodologicznego a możliwością rozwiązywania konkretnych problemów badawczych, osadzonych w kontekście pola problemowego danej dziedziny wiedzy.

Scharakteryzowana powyżej złożoność metodologicznej wiedzy pedagogicznej ma swoje przełożenie na praktykę badań pedagogicznych, rozumianą jako 
działalność nastawioną na „wytwarzanie informacji naukowych o funkcjonowaniu praktyki edukacyjnej. Informacje te w postaci diagnoz, ocen, teorii i raportów z weryfikacji teorii powstają w obszarze działania pedagogiki jako nauki, która posługuje się w swych dociekaniach regułami metodologii badań społecznych i humanistycznych" (Rubacha, 2013: 69). Jej prowadzenie wymaga uprzedniego wyposażenia badacza w teoretyczne oraz praktyczne zasoby wiedzy obowiązującej w pedagogice jako dyscyplinie naukowej. Wiedza teoretyczna otwiera albowiem możliwość:

1) szczegółowego scharakteryzowania i wyjaśnienia interesującego badacza przedmiotu badania;

2) osadzenia go w szeroko rozumianym kontekście naukowego eksplorowania;

3) uzyskania głębi jego rozumienia oraz interpretacji (Palka, 2010).

Wiedza praktyczna dostarcza z kolei gotowych i zalecanych wzorów badania. „Pozwala badaczowi poprawnie sformułować problem badawczy, określić przedmiot badań, postawić odpowiednie hipotezy, określić zmienne i ich wskaźniki, adekwatnie dobrać metody i narzędzia do badań (dzięki niej badacz wie, jakimi możliwościami dysponuje); podpowiada mu także, jak prowadzić badania, opracowywać dane empiryczne i opisywać uzyskane wyniki” (Bauman, 2013a: 84-85). Podsumowując: „w obszar praktyki badań pedagogicznych wchodzą więc: metarefleksja nad sposobami dochodzenia do wiedzy naukowej, teoria, którą dysponują i wykorzystują badacze, sposoby realizowania przez nich własnych projektów badawczych oraz wyniki ich badań” (Bauman, 2013a: 7).

Relację występującą pomiędzy kulturą metodologiczną, wiedzą oraz praktyką badań pedagogicznych zobrazowałam na rycinie 2 .

Jak można wnioskować z ryciny 2, wiedza stanowi zarówno punkt wyjścia, jak i efekt finalny podejmowanych przez pedagogów badań. Wiedza jako punkt wyjścia odzwierciedla zbiór teoretyczno-metodologicznych koncepcji, dyrektyw oraz wskazówek stanowiących odzwierciedlenie wiedzy pedagogicznej i wiedzy w pedagogice. Jest ona efektem celowościowych procesów edukacyjnych, wdrażających do przestrzegania imperatywów metodologicznej kultury oraz praktykowania jej form ostensywnych. Odpowiedzialne opanowanie przynależnych im treści oraz procedur postępowania powinno dawać gwarancję, że podejmowany przez badacza wysiłek zakończy się mniej lub bardziej spektakularnym sukcesem. Wiedza jako punkt dojścia $z$ reguły rozszerza dotychczasowy zbiór wiedzy pedagogicznej. Osadzając się w duchu konkretnej dyscypliny, stanowić powinna innowacyjne i twórcze wzbogacenie dotychczasowego zasobu jej informacji oraz podejmowanych w jej ramach praktyk badawczych. Jako efekt samodzielnie dokonywanych 
decyzji badawczych ugruntowana zostaje na bazie aksjologicznych i zasadotwórczych form kultury metodologicznej. W zależności od stopnia wypracowanych w jej ramach modyfikacji może się ona przyczyniać do stopniowego modyfikowania metodologicznego status quo lub też stanowić egzemplifikację jego poprawnej konserwacji.

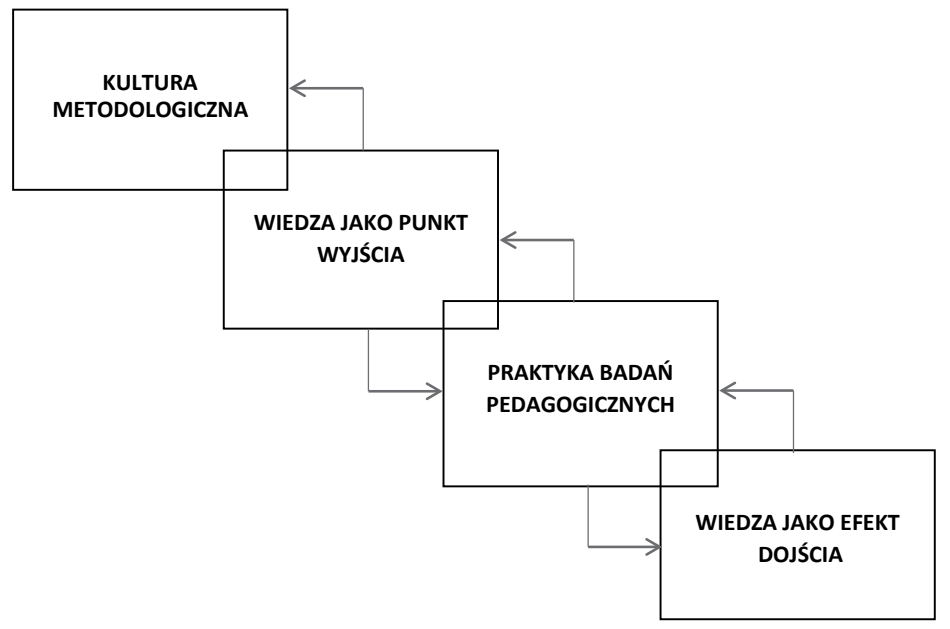

Ryc. 2. Relacja występującej pomiędzy kulturą metodologiczną, wiedzą oraz praktyką badań pedagogicznych. Źródło: opracowanie własne

Z tego punktu widzenia w praktykę badań pedagogicznych wpisane są również pewne napięcia, których (nie)rozwiązanie przekłada się zasadniczo na jakość podejmowanej praktyki oraz wytworzonej na jej podstawie wiedzy. Pierwsze z dostrzeganych przeze mnie napięć określam napięciem dziedzinowym, a drugie napięciem przedmiotowym.

Napięcie dziedzinowe odnosi się do relacji występujących pomiędzy pedagogiką a pozostałymi dziedzinami wiedzy. Określenie podporządkowanego, dominującego lub równorzędnego statusu czerpiących, dających lub współpracujących ze sobą dyscyplin jest zabiegiem ważnym, podnoszącym nie tylko świadomość badawczego postępowania (na przykład w zakresie selekcji literatury, sposobu jej wykorzystania, doboru określonych teorii oraz koncepcji), ale przede wszystkim przesądzającym o rodzaju prowadzonego przez badacza badania9. Świadome wykorzystanie różnorodnych zasobów wiedzy sprowadzone albowiem zostaje do

\footnotetext{
${ }^{9}$ W omawianym kontekście Stanisław Palka (2010a) wyróżnia następujące typy badań: multidyscyplinarne, transdyscyplinarne, interdyscyplinarne i badania z pogranicza.
} 
konieczności ustosunkowania własnego projektu badawczego względem któregoś z przedstawionych poniżej stwierdzeń:

1) wiedza pedagogiczna ufundowana zostaje na gmachu teoretycznego dorobku innych dyscyplin humanistycznych oraz społecznych, a jako taka:

a) nie jest w stanie wytworzyć samodzielnych konstruktów teoretycznych (radykalny wariant relacji),

b) prowadzi do wytworzenia teorii małego oraz średniego zasięgu, zredukowanych do wypracowanych w innych naukach teorii dużego zasięgu (umiarkowany wariant relacji);

2) wiedza pedagogiczna stanowi inspirującą podstawę rozwoju wiedzy w pedagogice;

3) pomiędzy wiedzą pedagogiczną $i$ wiedzą w pedagogice występuje symetria, „pedagog może korzystać z dorobku innych nauk i badacza w innych nauk mogą korzystać z dorobku pedagogiki, wzajemnie się inspirować poznawczo i badawczo" (Palka, 2010a: 345).

Napięcie przedmiotowe odnosi się do sytuacji paradygmatycznego zróżnicowania środowiska pedagogicznego, ufundowanego na odmiennych koncepcjach pedagogiki jako dyscypliny naukowej. Jego wymowną egzemplifikacją jest sytuacja występująca pomiędzy zwolennikami geodezyjnej i optymistycznej wizji pedagogiki bez granic (Melosik, 2003). Podczas gdy pierwsza z wytypowanych powyżej koncepcji pedagogiki pozostaje na straży pedagogicznej tradycji, jej tożsamościowego zakorzenienia i odrębności, druga uwodzi swą nonszalancją, emanuje otwarciem na wielość i zróżnicowanie przedmiotu badania. Pomiędzy tym uproszczonym, schematycznie wręcz przedstawionym ujęciem pedagogiki rozpościera się przestrzeń realnie doświadczanych problemów badacza: co i w jaki sposób mogę badać $\mathrm{w}$ dziedzinie pedagogiki? Jak moje badanie przekłada się na proces konstytuowania jej tożsamości? Czy istnieją nieprzekraczalne granice pedagogicznego poznania? Co stanowi fundament jej naukowości?

Trzeba się zatem zgodzić z Romanem Schulzem (1994: 101), że uprawianie pedagogiki

jeżeli ma być dojrzałe i autentycznie owocne, nie może być praktyką uprawianą czysto wegetatywnie. Nie może ono polegać na zwyczajnym prowadzeniu badań, bez jakiejkolwiek refleksji nad sensem prowadzonej działalności. Musimy wiedzieć, czym jest pedagogika, na czym polega specyfika jej przedmiotu i metod, jak ma się ona do innych dyscyplin naukowych, na jakim znajduje się szczeblu rozwoju, w jakiej relacji pozostaje do praktyki, do innych instytucji życia społecznego itp. Poszukiwanie samowiedzy, określanie własnego „ja”, musi zatem towarzyszyć nieuchronnie procesowi fabrykacji wiedzy pedagogicznej. W przeciwnym przypadku może sprawdzić się znana przepowiednia aforysty: jeżeli nie wiesz, dokąd idziesz, zajdziesz gdzie indziej. 


\section{Metodologiczna samowiedza pedagogiczna w kontekście przemian tożsamości pedagogiki jako dyscypliny naukowej}

Występujące w leksykalnych zasobach języka polskiego definicje pojęcia „samowiedza" mają charakter lakoniczny, określający ten specyficzny efekt ludzkiego poznania jako „wiedzę na temat samego siebie" ${ }^{10}$. Wzmożoną charakterystyką omawianego pojęcia, szczegółowym wyjaśnieniem powiązanych z nim mechanizmów oraz warunków istnienia zajmują się psycholodzy i filozofowie. Podczas gdy reprezentanci pierwszej z wyszczególnionych dyscyplin reprezentują empiryczne nastawienie do omawianego zjawiska, przedstawiciele drugiej koncentrują się na problemie jej epistemologicznego ugruntowania (zob. Piłat, 2013).

Kategoria metodologicznej samowiedzy pedagogicznej nie doczekała się jeszcze zdefiniowania, choć na istotną rolę samowiedzy w rozwoju tożsamości pedagogiki zwracał uwagę Roman Schulz (1994: 100) w artykule pt. Refleksje o tożsamości pedagogiki, a Andrea Folkierska (1990) wykorzystała ją do analizy świadomości metodologicznej pedagogów. Pierwszy w przytoczonych powyżej autorów pisze:

\footnotetext{
Wydaje się, że ważniejsza od pojęcia tożsamości jest kategoria samowiedzy. Sporo problemów nękających współczesnych pedagogów zyskuje inne naświetlenie, gdy spogląda się na nie raczej przez pryzmat dążenia ku samowiedzy niż z perspektywy określania, nadawania lub przebudowywania tożsamości. Tożsamość jakiegokolwiek podmiotu działania, a ściślej - jej kształtowanie się w kolejnych fazach rozwoju - zdaje się być etapowym wynikiem dążenia do samowiedzy, nie zaś jakąś właściwością, którą można byłoby dowolnie ustalać drogą publicznej debaty i samostanowienia.
}

Podążając za tropem zasugerowanym w powyższym cytacie, wartość analiz odnoszących się do zagadnienia samowiedzy pedagogiki uzasadniam następującymi tezami:

1) Wiedza o samym sobie jest najistotniejszym składnikiem tożsamości, stanowi podstawę świadomego udzielania odpowiedzi na pytania: kim jestem w roli zawodowej badacza-pedagoga?, do czego owo dyscyplinarne przypisanie mnie zobowiązuje?, na co uczula?, w czym ogranicza, a jednocześnie jakie obszary refleksyjnej samorealizacji stwarza?

2) Samowiedza jest zakładana przez wiele istotnych intuicji i rozumowań moralnych, kształtowanych na drodze świadomego uczestniczenia $\mathrm{w}$ akademickiej kulturze, respektowania kluczowych dla niej pryncypiów, możliwości ich uzasadnionego krytykowania, transmitowania i twórczego przekraczania - wytwarzania nowych jakości z zastanego status quo.

${ }^{10}$ http://sjp.pwn.pl/slowniki/samowiedza.html 
3) Samowiedza otwiera perspektywę przyszłości. Wychodząc od konkretnego „tu i teraz” może jednocześnie stanowić instrument uprawiania i kierowania rozwojem pedagogiki. Jak bowiem zauważa przywoływany już Roman Schulz (1994: 101), dążenie do samowiedzy pedagogiki „wpływa na identyfikację obszarów zjawisk interesujących pedagogów, dostarcza języka opisu tej rzeczywistości, oferuje kryteria ustanawiania priorytetów badawczych, ustala standardy wykonania dla operacji poznawczych, precyzuje osiągnięty przez dyscyplinę stopień immanentnego rozwoju, objaśnia jej stosunek do innych nauk itp.”.

4) Jest zatem samowiedza ściśle związana $z$ postulatem doskonalenia samego siebie, ze stopniowym przechodzeniem od tego, „jak jest”, do tego, „jak mogłoby być w przyszłości”.

5) „Bez samowiedzy niemożliwe wydaje się ucieleśnienie ideału szczęśliwego i dobrego życia” (Piłat, 2013: 222), co w odniesieniu do pedagogiki jako dyscypliny naukowej wiąże się z koniecznością pozyskania odpowiedzi na pytania o status pedagogiki, głównie za sprawą prowadzonego w jej ramach badania i generowanej na jego podstawie wiedzy.

6) „Samowiedza stoi u podstaw mówienia, ponieważ częścią samowiedzy jest znajomość sensu własnych wypowiedzi oraz zdolność do dostosowywania wypowiedzi do własnych myśli” (Piłat, 2013: 222).

Podejmując się zatem próby sformułowania roboczej definicji omawianego pojęcia, przez metodologiczną samowiedzę pedagogiczną rozumiem zbiór generowanych przez pedagogów sądów i wyobrażeń na temat pedagogiki jako dyscypliny naukowej, realizowanej w jej ramach praktyki badania oraz otrzymanego na jej podstawie efektu, przybierającego z reguły postać wiedzy pedagogicznej.

Ma ona charakter polifunkcjonalny:

1) ukierunkowujący praktykę badań pedagogicznych;

2) regulatywny względem zalecanych sposobów jej uprawiania;

3) demaskujący występujące w jej ramach nieprawidłowości i błędy;

4) wyznaczający wewnątrzdyscyplinarne kryteria kontroli jakości wytworów naukowych;

5) integrujący paradygmatyczną złożoność środowiska pedagogicznego;

6) inspirujący do wspólnie podzielanej troski o status pedagogiki jako dyscypliny naukowej.

Mechanizm jej wytwarzania regulowany jest na podstawie trojakiego rodzaju bodźców:

1) zróżnicowanych obszarów akademickiej kultury, odnoszących się do:

a) kultury społecznej, osadzającej praktykę badania pedagogicznego w społecznym i kulturowym kontekście jej obowiązywania, 
b) kultury metodologicznej, wyznaczającej formalne zasady jej wytwarzania,

c) kultury pedagogicznej, rozumianej jako mechanizm międzypokoleniowego przekazu występującego pomiędzy zróżnicowanymi uczestnikami społeczności akademickiej;

2) zasobu „świadomych i nieświadomych informacji zakodowanych w systemie nerwowym" wytwarzających ją osób (Kozielecki, 1986: 272). Informacje te mają swe źródła w: samodzielnej refleksji badacza, opiniach pozyskanych od reprezentantów innych dyscyplin naukowych oraz w szeroko rozumianym życiu społecznym (pedagogika w sferze publicznej);

3) celowo podejmowanego działania środowiska pedagogicznego na rzecz jej wytworzenia na drodze badania.

Syntetyczną reprezentację źródeł metodologicznej samowiedzy pedagogicznej stanowi rycina 3.

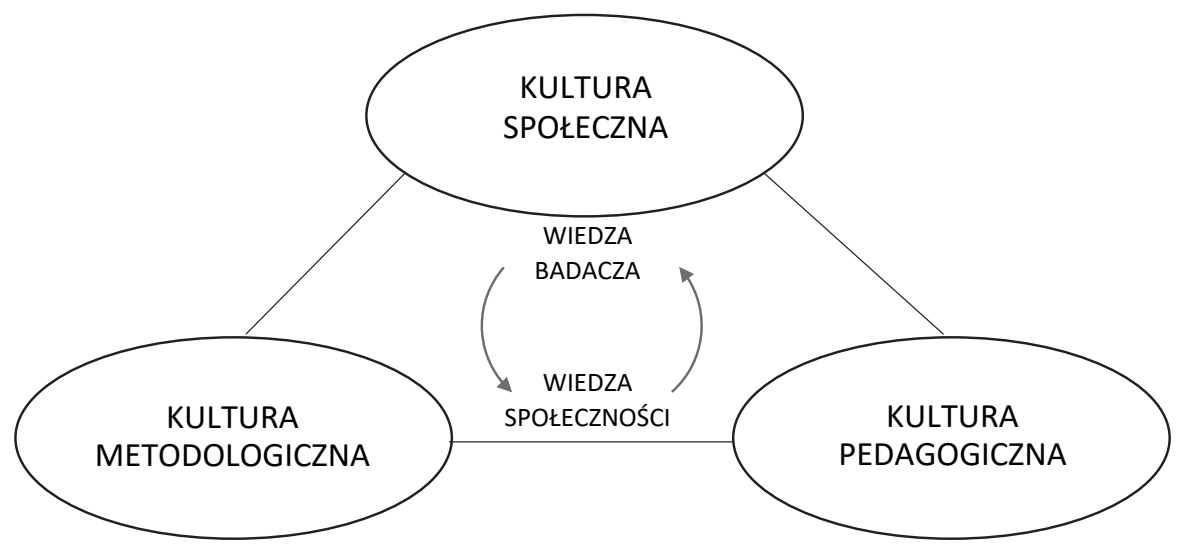

Ryc. 3. Płaszczyzny wytwarzania metodologicznej samowiedzy pedagogicznej Źródło: opracowanie własne

Tak dookreślony kontekst jej wytwarzania umożliwia sformułowanie co najmniej trzech przesłanek uzasadniających kierunek dalszego wywodu:

1) Każda $z$ wyszczególnionych na rycinie 3 dziedzin kultury akademickiej dostarcza odrębnego rodzaju danych, informacji, wiedzy, a także dopuszczalnych w jej ramach sposobów działania, wytwarzających stan tak jednostkowego, jak i zbiorowego poczucia tożsamości reprezentantów uniwersytetu. Odwołuje się on do: „systemu wartości intelektualnych, poznawczych, moralnych, estetycznych, rozpoznani[a] i stosowani[a] obowiązujących w da- 
nym środowisku reguł postępowania, emocjonalnego reagowania, rozwiązywania problemów naukowych, artystycznych, ale także codziennych sporów i konfliktów międzyludzkich, poczuci[a] odpowiedzialności za organizację i wyniki badań naukowych, jakość wykreowanych dzieł sztuki oraz kształcenia w uniwersytecie" (Górniewicz, Piotrowski, 2014: 186).

2) Zalecane sposoby badawczego oswajania świata (kultura metodologiczna), a także zasadniczy kierunek i/lub cel zróżnicowanych procesów edukacyjnych (kultura pedagogiczna) zakorzenione zostają w kulturze danego miejsca oraz czasu historycznego (kultura społeczna).

3) Zarówno zbiorowa, jak i jednostkowa płaszczyzna wytwarzania metodologicznej samowiedzy pedagogicznej powoduje, że ugruntowująca dorobek danej dyscypliny naukowej wiedza cyrkuluje. $Z$ jednej strony stanowi ona efekt zbiorowego wysiłku uczonych podejmowanego na rzecz krytycznego oglądu reprezentowanej przez nich dyscypliny wiedzy. Z drugiej, uzyskane na jej podstawie wnioski wytwarzane są na podstawie jednostkowo realizowanego badania, wchodzącego do informacyjnego obiegu danej dyscypliny za sprawą bezpośrednich lub pośrednich kanałów komunikacji naukowej (Boruszewski, 2017).

Pedagogiczna samowiedza metodologiczna ma także charakter głęboko kontekstualny, odzwierciedlający teoretyczno-metodologiczno-filozoficzną świadomość omawianej dyscypliny w trzech zgoła odrębnych kontekstach kultury. Ich syntetyczną charakterystykę stanowi rycina 4 .

Jak można wnioskować z ryciny 4, elementem formującym tożsamość pedagogiki jako dyscypliny naukowej jest sytuacja kryzysu, rozumianego jako:

stan załamania, który może zakończyć się destrukcją (zapaścią, unicestwieniem) lub zapowiedzią możliwego przesilenia i potencjalnego przełomu w funkcjonowaniu. Kryzys może dotyczyć określonego systemu politycznego, społecznego, kulturowego, osobowościowego. Pierwsza faza kryzysu jest zawsze związana z załamaniem i utratą dotychczasowego stanu równowagi, co wiąże się zawsze z poczuciem dyskomfortu. W drugiej fazie następuje uświadomienie objawów owego dyskomfortu i zidentyfikowanie jego przyczyn. W trzecim etapie pojawia się szansa na przezwyciężenie kryzysu poprzez przestrukturalizowanie całej sytuacji problemowej, nowe jej opisanie i zinterpretowanie. (Hejnicka-Bezwińska, 2011: 46)

Jego doświadczanie nieodzownie koresponduje więc z wytwarzaniem historycznie i epistemologicznie uwarunkowanych reguł budowy wypowiedzi na temat edukacji, składających się na zjawisko dyskursu edukacyjnego ${ }^{11}$ (Milerski, Śliwer-

${ }^{11}$ Zaznaczam, że w przytoczonym źródle (2000: 144) pojęcie dyskursu edukacyjnego zdefiniowane zostało jako: „1) uwarunkowane historycznie i epistemologicznie reguły budowy wypowiedzi 
ski, 2000). Nie ulega wątpliwości, że edukacja stanowi(ła) na tyle istotną domenę kultury, że odnotowywane w jej ramach zmiany podlegały zjawiskom zarówno zbiorowej, jak i jednostkowej (re)interpretacji.

\begin{tabular}{|c|c|c|c|c|}
\hline KULTURA II RZECZYPOSPOLITEJ & \multirow[b]{2}{*}{1} & $\begin{array}{l}\text { KULTURA REALNEGO } \\
\text { SOCJALIZMU }\end{array}$ & & $\begin{array}{c}\text { KULTURA DEMOKRATYCZNA } \\
\text { I RYNKOWA }\end{array}$ \\
\hline PEDAGOGIKA HUMANISTYCZNA & & $\begin{array}{l}\text { NAUKOWA PEDAGOGIKA } \\
\text { SOCJALISTYYZNA }\end{array}$ & II & $\begin{array}{c}\text { PEDAGOGIKA IN STATU } \\
\text { NASCENDI }\end{array}$ \\
\hline $\begin{array}{l}\text { - ufundowane na założeniu } \\
\text { o odrębności społ. } \\
\text { i humanistycznych od } \\
\text { przyrodniczych } \\
\text { - skoncentrowanie na } \\
\text { fenomenie ludzkiej } \\
\text { duchowości i dziejowości } \\
\text { - pluralizm i szeroki i kontekst } \\
\text { poznania } \\
\text { - łączenie teoretyczności } \\
\text { z filozoficznością } \\
\text { i historycznością } \\
\text { - emancypacyjny charakter } \\
\text { procesów edukacyjnych }\end{array}$ & $\begin{array}{l}P \\
E \\
D \\
A \\
G \\
O \\
G \\
\text { I } \\
K \\
\text { I }\end{array}$ & $\begin{array}{l}\text { - zideologizowana odmiana } \\
\text { pedagogiki empirycznej } \\
\text { - skoncentrowana na analizie } \\
\text { celowościowych procesów } \\
\text { edukacyjnych oraz tworzeniu } \\
\text { projektów edukacyjnych } \\
\text { i oświatowych } \\
\text { - legitymizowanie ideologii } \\
\text { marksistowsko-leninowskiej } \\
\text { - ahistoryczność, } \\
\text { afilozoficzność, produkt } \\
\text { ofensywy ideologicznej ZSRR } \\
\text { - uprzedmiotowiający charakter } \\
\text { procesów edukacyjnych }\end{array}$ & $\begin{array}{l}P \\
E \\
D \\
A \\
G \\
O \\
G \\
\text { I } \\
K \\
\text { I }\end{array}$ & $\begin{array}{l}\text { - wieloparadygmatyczność } \\
\text { - wielonurtowość } \\
\text { - multijęzykowość } \\
\text { - wewnętrzna dyferencjacja } \\
\text { - zróżnicowane nurty, kierunki } \\
\text { i szkoły myślenia }\end{array}$ \\
\hline
\end{tabular}

Ryc. 4. Kontekst rozwoju pedagogiki jako dyscypliny naukowej

Źródło: opracowanie własne na podstawie: Hejnicka-Bezwińska, 2006; 2008; 2011; Milerski, 2006; Wołoszyn, 2006; Sztompka, 2006

W przypadku metodologicznej samowiedzy pedagogicznej tendencja do problematyzowania konstytuujących ją zjawisk, zaleceń i oczekiwań może stanowić strategię poznawczego "przepracowywania” efektów doświadczanego przez pedagogów kryzysu. Zdaniem Teresy Bauman (2013a: 7) „przyglądając się praktykom badawczym, możemy wnioskować o jakości wiedzy metodologicznej środowiska pedagogicznego".

Radykalny charakter przekształceń występujących zarówno w praktyce badań pedagogicznych, jak i wytwarzanej na ich podstawie wiedzy, nałożył na barki reprezentantów tej dyscypliny zjawisko traumy kulturowej, odzwierciedlającej „wstrząs spowodowany zmianą społeczną, która dotyka domeny kultury, a w konsekwencji tożsamości zbiorowej i jednostkowej" (Sztompka, 2006: 473). Jej doświadczenie powoduje praktyczne naruszenie zasady, zgodnie z którą „ciągłość, pewność, stabilność, bezpieczeństwo, przewidywalność sytuacji społecznych,

na temat edukacji; 2) obecny w szkole gatunek mowy, będący rodzajem wyspecjalizowanej praktyki komunikatywnej, która ma swoje reguły i prawa; 3) zdarzenie interakcyjne, podczas którego dochodzi do wymiany komunikatów w procesie edukacyjnym". 
a także trwałość i jednoznaczność swojej sytuacji w społeczeństwie i wynikających stąd imperatywów działania - stanowią dla ludzi wartości same w sobie, autoteliczne, niezależne od treści odpowiednich oczekiwań czy reguł" (Sztompka, 2006: 457). Jednym z możliwych sposobów radzenia sobie z wyrastającym na tej podstawie odczuciem dezorientacji i dezintegracji są

zabiegi interpretacyjne i reinterpretacyjne mające zmienić percepcję zmian inicjalnych, a także stanów i sytuacji traumatogennych. Celem strategii są tu schematy interpretowania i identyfikowania traumy dostępne w świadomości zbiorowej, a metodą - intensywny dyskurs wokół traumy, nasilenie potocznych debat publicznych czy aktywności zbiorowej w kierunku zmiany dotychczasowej perspektywy. (Sztompka, 2006: 467)

W kontekście rozwoju interesującej mnie dyscypliny zjawisko traumy kulturowej odcisnęło swoje piętno na wszystkich możliwych aspektach akademickiej kultury. W płaszczyźnie relacji występujących pomiędzy uniwersytetem a społeczeństwem wiązało się ono z doświadczeniem przejścia od nastawionej na rozwój i odbudowę utraconej demokracji państwa polskiego kultury II Rzeczypospolitej, poprzez całkowite zanegowanie konstytutywnych dla niej tendencji za sprawą ideologicznej indoktrynacji i ofensywy kultury realnego socjalizmu, aż po sytuację doświadczenia wolności, prawa do indywidualności oraz wynikającej z jego różnicy, odnoszących się do uwarunkowań kultury demokratycznej oraz rynkowej (Sztompka, 2006). W tak zarysowanym kontekście:

pedagogika polska w znacznej mierze przystosowała się do naprzemiennych wahnięć systemu jej obramowania raz otwierających, raz zamykających go. W efekcie przestała podejmować podstawowe pytania teoretyczne, aksjologiczne, metodologiczne i dokonała samolikwidacji akademickiego dyskursu paradygmatycznego, koncentrując się na wąsko instrumentalnych zadaniach metodycznych, stając się sama elementem bezwiednej praktyki, praktyki - dodajmy - schizofrenicznie rozdartej pomiędzy to, co publiczne i przynoszące korzyść, a to, co prywatne i broniące sensu oraz zachowania tożsamości, praktyki nie dającej żadnej nadziei, zmuszającej do przetrwania jako jedynego celu życia. (Kwieciński, 1994: 16)

Radykalne przemiany społecznej kultury musiały zatem wywołać przemiany kultury metodologicznej i pedagogicznej. W tym akurat kontekście szczególnego znaczenia nabierają:

1) wydarzenia okresu 1939-1989, które, deprawując intelektualne dokonania tradycyjnej pedagogiki humanistycznej ${ }^{12} \mathrm{w}$ Polsce, zmierzały jednocześnie

12 Pedagogika humanistyczna to „syntetyczne określenie tych nurtów i kierunków pedagogicznych, którym początek dało metodologiczne wyodrębnienie nauk humanistycznych (Geisteswissenschaften, nauk o duchu) przez W. Diltheya, inaczej mówiąc przyjęcie założeń antynaturalizmu" (Hej- 
do kulturowej adaptacji i praktycznej realizacji (w sensie praktyki badań i praktyki edukacyjnej) założeń naukowej pedagogiki socjalistycznej. Według Teresy Hejnickiej-Bezwińskiej (2008: 427) jej wprowadzenie wiązało się z doznawaniem "przemocy symbolicznej i ideologicznej w okresie stalinizmu [kierowanej] wobec: 1) nauki - uniwersytetów - wolności akademickich, 2) szkoły jako strukturalnego elementu systemu oświatowego, 3) nauczycieli - uczniów i innych podmiotów edukacji”. Funkcjonowanie omawianego modelu pedagogiki wiązało się z:

a) wytypowaniem ideologicznie ukierunkowanych celów poznania, kształcenia i wychowania,

b) podporządkowaniem zarówno badawczej, jak i praktycznej płaszczyzny omawianej dyscypliny ideałowi pedagogiki empirycznej, przenoszącej humanistycznie ugruntowane zainteresowanie istotą człowieka na rzecz efektywnych sposobów jego indoktrynacji i podporządkowywania;

2) transformacja ustrojowa roku 1989, „korespondując[a] z rozpadem imperium sowieckiego, której celem było rozmontowanie ładu narzuconego suwerennemu państwu i zastąpienie go ładem policentrycznym, przywracającym demokrację, wolny rynek, własność prywatną, wolność słowa, zrzeszania się, praw człowieka i wolności obywatelskiej" (Hejnicka-Bezwińska, 2008: 427).

Prymat wolności nad zniewoleniem spowodował uruchomienie oporu depozytariuszy kapitału pedagogiki wobec zmian, a z drugiej strony „wolę zawłaszczania prawa do diagnozowania ujawniającego się dyskomfortu poznawczego" (Hejnicka-Bezwińska, 2011: 47). Z tego być może względu doświadczamy dziś sytuacji, w której pogłębiony wgląd w teoretyczno-metodologiczne zasoby pedagogiki nie sprzyja ugruntowywaniu jej pozycji w nauce.

W roku 1994 debatujący nad kwestią tożsamości i samowiedzy pedagogiki Roman Schulz (1994: 100) pisze: „Dopóki rozstrzygnięcia identyfikacyjne nie nastąpią, pedagogika (polska) pozostanie nauką chorą, obciążoną własną (w domyśle - niedobrą) przeszłością; nauką nie mającą kompetencji, a może nawet tytułu do odgrywania w przyszłości roli intelektualnego narzędzia praktyki edukacyjnej”.

nicka-Bezwińska, 2008: 495). Interesującego studium opisu myślenia oraz działania pedagogicznego w okresie międzywojennym dokonał Mirosław M. Szymański (2016). W książce Myślenie i działanie pedagogiczne w Drugiej Rzeczypospolitej. Esej polityczno-oświatowy dokonuje on charakterystyki czterech narodowych ruchów pedagogicznych, takich jak: ruch nowej szkoły, ruch samorządów uczniowskich, ruch uniwersytetów ludowych oraz ruch przyjaciół dzieci. Ich charakterystyka, splatając ideowe oraz praktyczne fundamenty działania ówczesnych pedagogów, stanowi ciekawą reprezentację ówczesnego „ducha dyscypliny”. 
Osiem lat później Tadeusz Lewowicki (2001: 10), zaliczając pedagogikę do „dyscyplin stosunkowo młodych, niedysponujących rozwiniętymi metodologiami własnymi i zaniedbanych w stosowaniu zaleceń metodologicznych”, zauważa, że:

wyrazem [młodości pedagogiki jako dyscypliny naukowej - J.S.S.] jest na przykład brak pedagogiki w niektórych klasyfikacjach nauk, urzędowe przypisywanie pracom z zakresu pedagogiki stosunkowo niskiej wartości (świadczą o tym m.in. sposoby przyznawania przez KBN punktów za publikacje i prace awansowe), relatywnie niskie nakłady na badania podejmowane na gruncie pedagogiki, niepisana, zazwyczaj niska pozycja pedagogiki w środowiskach akademickich. Pomińmy w tym miejscu sprawę trafności takich opinii i skojarzonych z nimi zachowań. Opinie te, oceny, niekiedy stereotypy w spostrzeganiu pedagogiki są jednak faktami i zjawiskami społecznymi, których nie należy bagatelizować.

Dziesięć lat później diagnozy pedagogiki dokonuje między innymi Zbigniew Kwieciński (2011: 72):

Pedagogika jako dyscyplina, której częścią jest andragogika, nie jest dyscypliną paradygmatyczną, tzn. nie tylko nie dysponuje zespołem trwałych i spójnych twierdzeń, akceptowanych w danym okresie przez społeczność uczonych, a następnie obalonych przez kolejną teorię, ale także w tym sensie, że nowe wzory myślenia (tzn. paradygmaty) obowiązują równocześnie ze starymi. Jest więc to dyscyplina wielonurtowa i poliparadygmatyczna (jeśli wzór, model czy nurt myślenia nazwiemy metaforycznie paradygmatem).

W roku 2016 opisująca kondycję pedagogiki w warunkach zmiany kulturowej Teresa Hejnicka-Bezwińska (2016: 400) kończy swe rozważania pytaniem: „Jaka jest więc nasza tożsamość i tożsamość każdego nas z osobna? Czy uzyskiwanie stopni i tytułów naukowych przez osoby wchodzące do pedagogiki w ramach wymiany międzypokoleniowej oznacza także zmianę tożsamości pedagogiki??"

Z zestawionego powyżej zbioru cytatów wyłania się obraz pedagogiki jako dyscypliny w stanie tworzenia. Akcentowana po przełomie roku 1989 potrzeba zbudowania tożsamości pedagogiki zachowuje swoją aktualność. Po upływie niemalże trzydziestu lat od momentu doznania drugiego kryzysu pedagogiki w dalszym ciągu pytamy: co to właściwie znaczy być badaczem-pedagogiem i z czym owa przynależność się wiąże? Występujące w literaturze pedagogicznej diagnozy kondycji pedagogiki mają charakter ambiwalentny, pozostawiający ich czytelnikowi pole do refleksyjnej interpretacji. Elementem przyciągającym uwagę jest jednak analiza występujących w jej ramach problemów, trudności i blokad w możliwościach dalszego rozwoju. Z jakiegoś powodu bliżej jest nam (pedagogom) do wytwarzania swej samowiedzy z perspektywy jastrzębia, „wyglądająceg[o] tego, co dałoby się 
rozerwać na strzępy i zjeść”, a nie dla przykładu ptaka z sercem gołębia, „patrzącego na świat dobrotliwie i radośnie” (Kwieciński, 2011: 15). Nie bez znaczenia pozostaje też język prowadzonego autoopisu. Na przykładzie czterech zestawionych powyżej cytatów rysuje się obraz pedagogiki jako dyscypliny chorej, obciążonej własną przeszłością, niekompetentnej, o stosunkowo niskiej wartości oraz pozycji zarówno w nauce, jak i społeczeństwie. Listę przypisywanych pedagogice przez pedagogów epitetów można znacząco rozszerzać i doszukiwać się zwrotów pozytywnie wartościujących w natłoku określeń pejoratywnych, eksponujących „nędzę pedagogiki i jej własnego zaprzeczenia” (Gnitecki, 2001: 20). Jaka jest zatem funkcja tej pedagogicznej autodiagnozy? Czy przez przypadek wyłaniający się spod ostrza krytycznego oglądu obraz dyscypliny nie przyczynia się do ugruntowywania niezadowalającej pedagogów pozycji pedagogiki? Jeżeli tak, to czy możliwe jest takie tworzenie pedagogicznej samowiedzy, które to, pozostając przy kluczowym diagnozowaniu występujących w jej ramach problemów, nie doprowadza jednocześnie do jej autodewaluacji?

\section{Zakończenie}

Rozważania podejmowane w ramach niniejszego artykułu skoncentrowane zostały na zjawisku metodologicznej samowiedzy pedagogicznej. Warunki jej wytwarzania osadzone zostały w trzech zróżnicowanych kontekstach rozwoju pedagogiki jako dyscypliny naukowej (pedagogika okresu II Rzeczypospolitej, socjalistyczna pedagogika naukowa, pedagogika in statu nascendi). W odniesieniu do ostatniego z wyszczególnionych modeli pedagogiki jako dyscypliny naukowej należą się słowa dodatkowego komentarza.

Za pedagogikę w stanie tworzenia uznaję dyskursywnie konstytuowany zbiór rozmaitych przeświadczeń oraz sądów odnoszących się do statusu tej dyscypliny, jej naukowej oraz społecznej użyteczności, konstruktywnego kierunku rozwoju, a także jego blokad i ograniczeń. Wytwarzana na jego podstawie wiedza ma zatem charakter złożony, stanowi albowiem przejaw dyskursu o edukacji, rozumianego przez Teresę Hejnicką-Bezwińską (2008: 467) jako „dyskurs podmiotów edukacji, z których każdy ma równe prawo do wyrażania swoich opinii, przekonań, poglądów, niezależnie od wiedzy, kompetencji językowych i typu interesu osobistego". W samowiedzy tej dyscypliny, niczym w soczewce, odbijają się głosy: 1) reprezentantów wielorakich dyscyplin naukowych, głównie społecznych i humanistycznych, 2) publicystów, decydentów władzy, 3) zaangażowanych w pedagogię nauczycieli, uczniów, rodziców, reprezentantów instytucji oświatowych (Ostrowicka, 2015). Pomiędzy wszystkimi 
wyszczególnionymi powyżej podmiotami toczy się zatem zacięta dyskusja o kształt i kierunek dalszego rozwoju współczesnej edukacji.

Metodologiczna samowiedza pedagogiczna, jako jeden z wyspecjalizowanych obszarów owej społecznej debaty stanowi w zasadzie efekt dyskursu naukowego. Jak bowiem konstatuje Helena Ostrowicka (2015: 43) „,asymilacja kategorii dyskursu w refleksji nad problematyką i metodologią badań naukowych, czyli nad procedurami, zasadami i efektami wytwarzania wiedzy naukowej, wiąże się z przyznaniem szczególnego znaczenia językowi i władzy nazywania, kategoryzowania, opisywania, wyjaśniania zjawisk poddawanych naukowej eksploracji”. Język ten, będąc narzędziem transmisji i zmiany scharakteryzowanych w artykule przejawów kultury, może stanowić „czynnik wytwarzający wewnętrzną solidarność zbiorowości i zarazem jej separację od zbiorowości zewnętrznych. Mówienie wspólnym językiem, a zatem rozumienie się nawzajem, to ważny element środowiskowej czy grupowej tożsamości, poczucia my” (Sztompka, 2006: 291). Rozwój języka pedagogiki jako dyscypliny naukowej, a w szczególności powstanie zwrotów służących do jej samoopisu, może stanowić ważką płaszczyznę autoidentyfikacji pedagogów. W tym kontekście ważną wydaje się konstatacja Joanny Rutkowiak (1994: 86), zgodnie z którą: „obecna zmiana tożsamości naszej pedagogiki polega na przypominaniu, odsłanianiu, ujawnianiu i tworzeniu się wielu jej jakości, na uprawnionym konstytuowaniu się jej multijęzykowości”. Jednoczesne zakorzenienie języka współczesnej pedagogiki z teraźniejszości i czasie minionym, w specjalistycznych wytworach kultury naukowej i jej potocznych, publicystycznych, religijnych, literackich itp. odpowiednikach może stanowić zarówno o jego sile, jak i dyscyplinarnie diagnozowanej słabości. W pedagogicznym oglądzie podejmowanych przez pedagogów aktywności współwystępują co najmniej dwie perspektywy. Pierwsza ugruntowana jest na podstawie dyskursu traumy, odnoszącego się do opisywania i diagnozowania destabilizujących, dezorganizujących i dezorientujących konsekwencji doświadczanych przez pedagogów zmian (Sztompka, 2006). Druga, stanowiąc interpretacyjne zaprzeczenie dyskursu pierwszego, wartościuje występujące w pedagogice zmiany w sposób pozytywny, przenosząc tym samym sedno toczących się w jej ramach analiz na sukcesy i dokonania pedagogów (zob. Kwieciński, 2011). Który z wyszczególnionych powyżej typów dyskursu ma charakter kluczowy dla generowania metodologicznej samowiedzy pedagogicznej? Czy pośród nich uzewnętrzni się inna (być może inne) perspektywa wypowiadania się na temat pedagogiki i powstających w jej ramach wytworów? To z pewnością pytania, na które odpowiedź pozostaje nieznana. Ich sformułowanie traktuje więc jako punkt wyjścia dla dalszego eksplorowania zjawiska metodologicznej samowiedzy pedagogicznej oraz towarzyszących jej wytwarzaniu mechanizmów. 


\section{Literatura}

Bauman T. (red.). (2013). Praktyka badań pedagogicznych. Kraków.

Bauman T. (2013a). Kompetencje badawcze a świadomość metodologiczna. [W:] T. Bauman (red.). Praktyka badań pedagogicznych. Kraków.

Benton T., Craib I. (2003). Filozofia nauk społecznych: od pozytywizmu do postmodernizmu. Wrocław. Boguski J. (2013). Zarządzanie wiedza w uczelni wyższej. „Nauka i Szkolnictwo Wyższe” nr 2/42, https://goo.gl/xH0UnJ, dostęp: 10.04.2017.

Boruszewski J. (2017). Dostępność wiedzy naukowej a jej intersubiektywna komunikowalność. [W:] E. Kulczycki (red.). Komunikacja naukowa w humanistyce. Poznań.

Braidotti R. (2013). The Posthuman. Cambridge.

Czarnecki K.M. (red.). (2009). Nowy leksykon metodologiczny. Sosnowiec.

Folkierska A. (1990). Samowiedza pedagogiki wobec współczesnej świadomości metodologicznej. „Ruch Pedagogiczny” nr 5-6, s. 30-41

Fukuyama F. (2009). Koniec historii. Kraków.

Gnitecki J. (2001). Przemiany metodologii badań pedagogicznych. [W:] J. Krajewski, T. Lewowicki, J. Nikitorowicz (red.). Problemy wspótczesnej metodologii. Olecko.

Goriszowski W. (2006). Podstawy metodologiczne badań pedagogicznych. Warszawa.

Górniewicz J., Piotrowski P. (2014). Uniwersytet jako źródło wartości kultury. Warszawa-Olsztyn.

Hejnicka-Bezwińska T. (1989). W poszukiwaniu tożsamości pedagogiki. Świadomość teoretyczno-metodologiczna wspótczesnej pedagogiki polskiej. (Geneza i stan). Bydgoszcz.

Hejnicka-Bezwińska T. (2006). Pedagogika pozytywistyczna. [W:] Z. Kwieciński, B. Śliwerski (red.). Pedagogika. Podręcznik akademicki, t. 1. Warszawa.

Hejnicka-Bezwińska T. (2008). Pedagogika ogólna. Podręcznik akademicki. Warszawa.

Hejnicka-Bezwińska T. (2011). Podobieństwa i różnice w ujawnianiu i przezwyciężaniu kryzysów polskiej pedagogiki XX wieku. [W:] M. Nowak-Dziemianowicz, P. Rudnicki (red.). Pedagogika. Zakorzenienie i transgresja. Wrocław.

Hejnicka-Bezwińska T. (2016). Praktyka edukacyjna w warunkach zmiany kulturowej. (W poszukiwaniu logiki zmian). Warszawa.

Jaworska-Witkowska M. Kwieciński Z. (2011). Nurty pedagogii. Naukowe, dyskretne, odlotowe. Kraków.

Knyazheva I.A. (2012). Methodological culture as a socio-cultural phenomenon. „Journal Education and Pedagogical Science" No. 3, Vol. 152, https://goo.gl/5vIrli, dostęp: 5.03.2017.

Kowalewski J., Piasek W. (red.). (2010). Zwroty badawcze w humanistyce. Konteksty poznawcze, kulturowe i społeczno-instytucjonalne. Olsztyn.

Kozielecki J. (1986). Psychologiczna teoria samowiedzy. Warszawa.

Krajewski J., Lewowicki T., Nikitorowicz J. (red.). (2001). Problemy wspótczesnej metodologii. Olecko.

Kubinowski D., Nowak M. (2006). Metodologia pedagogiki zorientowanej humanistycznie. Kraków.

Kwiatkowska H. (1994). (red.). Ewolucja tożsamości pedagogiki. Warszawa.

Kwieciński Z. (1991). Nieobecne dyskursy. Toruń.

Kwieciński Z. (1994). Mimikra czy sternik. Dramat pedagogiki w sytuacji przesilenia formacyjnego. [W:] H. Kwiatkowska (red.). Ewolucja tożsamości pedagogiki. Warszawa.

Kwieciński Z. (2011a). Pedagogika po przejściach - aspekty pozytywne. [W:] M. Nowak-Dziemianowicz, P. Rudnicki (red.). Pedagogika. Zakorzenienie i transgresja. Wrocław. 
Kwieciński Z. (2011b). Podwójne „przesunięcie paradygmatyczne” jako potrójne złudzenie. [W:] M. Jaworska-Witkowska, Z. Kwieciński (red.). Nurty pedagogii. Naukowe, dyskretne, odlotowe. Kraków.

Kwieciński Z., Śliwerski B. (red.). (2006). Pedagogika. Podręcznik akademicki, t. 1. Warszawa.

Kwieciński Z., Witkowski L. (1990). Ku pedagogii pogranicza. Toruń.

Lewowicki T. (2001). Szkic do dziejów metodologii pedagogiki (czyli o czym warto pamiętać czytając niniejszy zbiór opracowań). [W:] J. Krajewski, T. Lewowicki, J Nikitorowicz (red.). Problemy współczesnej metodologii. Olecko.

Lewowicki T. (2006). Szkic do dziejów metodologii pedagogiki. [W:] D. Kubinowski, M. Nowak (red.). Metodologia pedagogiki zorientowanej humanistycznie. Kraków.

Lyotard J.F. (1997). Kondycja ponowoczesna. Raport o stanie wiedzy. Warszawa.

Melosik Z. (1993). Epistemologia postmodernizmu. [W:] Z. Kwieciński (red.). Nieobecne dyskursy. Część III. Toruń.

Melosik Z. (2003). Edukacja, młodzież i kultura wspótczesna: kilka uwag o teorii i praktyce pedagogicznej. „Chowanna”, 1, s. 19-37.

Milerski B. (2006). Pedagogika kultury. [W:] Z. Kwieciński, B. Śliwerski (red.). Pedagogika. Podręcznik akademicki, t. 1. Warszawa.

Milerski B., Śliwerski B. (red.). (2000). Pedagogika. Leksykon PWN. Warszawa.

Nowak-Dziemianowcz M., Rudnicki P. (red.). (2011). Pedagogika. Zakorzenienie i transgresja. Wroclaw.

Ostrowicka H. (2015). Przemyśleć z Michelem Foucaultem edukacyjne dyskursy o młodzieży. Dyspozytyw i urządzanie. Kraków.

Palka S. (red.). (1998). Orientacje w metodologii badań pedagogicznych. Kraków.

Palka S. (red.). (2004). Pogranicza pedagogiki i nauk pomocniczych. Kraków.

Palka S. (2010a). Badania z pogranicza pedagogiki i innych nauk. [W:] S. Palka (red.). Podstawy metodologii badań w pedagogice. Gdańsk.

Palka S. (2010b). Wiedza w pedagogice i wiedza pedagogiczna. [W:] J. Piekarski, D. Urbaniak-Zając, K.J. Szmidt (red.). Metodologiczne problemy tworzenia wiedzy w pedagogice. Oblicza akademickiej praktyki. Kraków.

Palka S. (2011). Teoretyczność i praktyczność wiedzy pedagogicznej. [W:] T. Hejnicka-Bezwińska (red.). Pedagogika ogólna. Dyskursy o stanie naukowym i dydaktycznym. Bydgoszcz.

Petrusek M., Miltová A., Vodáková A. (1994). Sociologickè skoly, smèry, paradigmata. „Sociologickŷy ùstav" AV ČR, Praha, s. 16.

Piekarski J. (2013). Badawcza praktyka i jakość wiedzy - wybrane uwarunkowania. [W:] T. Bauman (red.). Praktyka badań pedagogicznych. Kraków.

Piekarski J., Urbaniak-Zając D., Szmidt K.J. (red.). (2010). Metodologiczne problemy tworzenia wiedzy w pedagogice. Oblicza akademickiej praktyki. Kraków.

Piłat M. (2013). Samowiedza. [W:] R. Ziemińska (red.). Przewodnik po epistemologii. Kraków.

Radziewicz-Winnicki A. (2011). Świadomość społeczna a stan współczesnej rodzimej pedagogiki. (Kilka zindywidualizowanych refleksji z perspektywy pedagogiki społecznej). [W:] M. Nowak-Dziemianowicz, P. Rudnicki (red.). Pedagogika. Zakorzenienie i transgresja. Wrocław.

Rubacha K. (2008a). (red.). Konceptualizacje przedmiotu badań pedagogiki. Kraków.

Rubacha K. (2008b). Metodologia badań nad edukacją. Warszawa.

Rubacha K. (2013). Metodologiczna analiza praktyki badań pedagogicznych. [W:] T. Bauman (red.). Praktyka badań pedagogicznych. Kraków. 
Rutkowiak J. (1994). Wielość języków pedagogiki a problem jej tożsamości. [W:] H. Kwiatkowska (red.). Ewolucja tożsamości pedagogiki. Warszawa.

Rutkowiak J. (1995a). Odmiany myślenia o edukacji. Kraków.

Rutkowiak J. (1995b). Pulsujące kategorie jako wyznacznik mapy odmian myślenia o edukacji. [W:] J. Rutkowiak (red.). Odmiany myślenia o edukacji. Kraków.

Schulz R. (1994). Refleksje o tożsamości pedagogiki. [W:] H. Kwiatkowska (red.). Ewolucja tożsamości pedagogiki. Warszawa.

Sikora M. (2013). Świadomość naukowa. [W:] K. Sztalt, M. Zemło (red.). Formy świadomości spoŁecznej. Lublin.

Sztalt K., Zemło M. (2013). Formy świadomości społecznej. Lublin.

Sztompka P. (2006). Socjologia. Analiza społeczeństwa. Kraków.

Szymański M.S. (2016). Myślenie i działanie pedagogiczne w Drugiej Rzeczypospolitej. Esej polityczno-oświatowy. Warszawa.

Śliwerski B. (2009). Wspótczesna myśl pedagogiczna. Znaczenia, klasyfikacje, badania. Kraków.

Wołoszyn S. (2006). Oświata i wychowanie w XX wieku. [W:] Z. Kwieciński, B. Śliwerski (red.). Pedagogika. Podręcznik akademicki, t. 1. Warszawa.

Ziemińska R. (red.). (2013). Przewodnik po epistemologii. Kraków. 